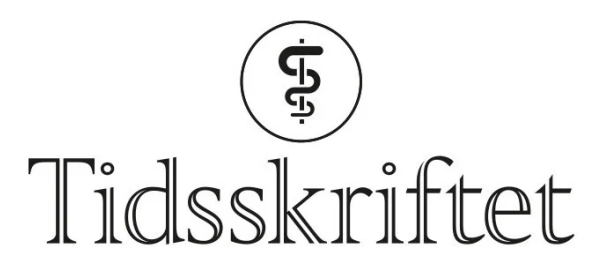

DEN NORSKE LEGEFORENING

\title{
Covid-19: Én verden, én helse
}

\section{LEDER}

\author{
HANNAH JOAN JØRGENSEN \\ hannah.jorgensen@vetinst.no \\ Hannah Joan Jørgensen er veterinær, dr.med.vet, med fagansvar for zoonoser ved \\ Veterinærinstituttet. \\ Forfatteren har fylt ut ICMJE-skjemaet og oppgir ingen interessekonflikter.
}

\section{CARLOS DAS NEVES}

Carlos das Neves er veterinær, DVM/ph.d og direktør for forskning og internasjonalisering ved Veterinærinstituttet.

Forfatteren har fylt ut ICMJE-skjemaet og oppgir ingen interessekonflikter.

\section{Trass i varsler fra forskere klarte ikke verdenssamfunnet å forhindre covid-19-pandemien.}

Det var tilfeldigheter som gjorde at det nye viruset oppstod, men det var ikke tilfeldig at det var hos flaggermus. Det var heller ikke tilfeldig at det ble overført til mennesker og fikk global spredning. Forskere forutså at et nytt koronavirus ville kunne overføres fra flaggermus til mennesker i Kina (1). Til tross for denne kunnskapen ble ikke utbruddet forhindret.

Zoonoser er smittsomme sykdommer som kan overføres fra dyr til mennesker, enten direkte eller indirekte via vektorer eller mat. Zoonoser kan også smitte fra mennesker til dyr, slik influensa $\mathrm{A}\left(\mathrm{H}_{1} \mathrm{~N}_{1}\right) \mathrm{pdmog}$ gjorde til svin i Norge (2). I tidligere tider var zoonoser en stor folkehelsebyrde i Norge. Det var den gang vi drakk upasteurisert melk, levde tettere på dyrene, manglet kunnskap om hygiene og hadde dårligere kontroll på dyrehelsen. Mens tradisjonelle zoonoser nå er under kontroll i Norge, håndterer vi med økende frekvens nye, importerte smittestoff av zoonotisk opphav. Pandemier er gammelt nytt, men spredningshastigheten er ny.

Mennesker, dyr og miljø deler et reservoar av smittestoffer, og fremmarsjen av nye sykdommer drives av komplekse interaksjoner mellom disse tre. Endring i samspillet kan drive genetisk endring hos patogene mikroorganismer, og nye varianter med høyere virulens, nye vertsspekter og nye smitteveier kan oppstå.

Dyreriket er opphavet til om lag 6o-70 \% av sykdommer på fremmarsj (emerging/reemerging infectious diseases). Av disse kommer $75 \%$ opprinnelig fra ville dyr (3). Flaggermus, den nest mest tallrike ordenen av pattedyr på kloden, er gjenganger som opphav til zoonotiske og pandemiske virus som ebola, sars, mers, nipah, hendravirus og rabies (4.). Med unntak av rabies gir ikke disse sykdom hos flaggermus. 
Flaggermus spiller en viktig rolle i friske økosystemer, men utgjør virale «heksegryter» og er reservoar for mange virustyper og varianter. Dette skyldes immunologiske og fysiologiske forhold samt populasjonsstørrelse og høy dyretetthet i enkelte flaggermuskolonier (5).

«Begrepet 'én helse' erkjenner en gjensidig avhengighet mellom humanhelse, dyrehelse og miljøhelse»

Med økt kontakt mellom mennesker og ville dyr øker sannsynligheten for at smittestoff kan overføres mellom artene. Forflytning av dyrepopulasjoner og skiftninger i dyretetthet kan endre kontaktflaten mellom mennesker og ville dyr. Menneskeskapte påvirkninger som avskoging, utvikling av jordbruksland, intensivering av husdyrproduksjon, urbanisering og klimaendringer reduserer størrelsen og mangfoldet i ville dyrs habitater og kan i ytterste konsekvens tilrettelegge for nye pandemier. I Malaysia migrerte flaggermuskolonier som følge av avskoging. Påfølgende økt nærhet mellom flaggermus og mennesker kan ha bidratt til at nipah-viruset senere ble overført fra flaggermus til gris og mennesker (므).

Dyremarkeder, handel med ville dyr og konsum av kjøtt fra ville dyr som flaggermus og pangolin innebærer en risiko for smitteoverføring mellom vill fauna og mennesker. Det krever langsiktig, holdningsskapende arbeid å endre denne typen risikoatferd.

Begrepet «én helse» erkjenner en gjensidig avhengighet mellom humanhelse, dyrehelse og miljøhelse og fremmer en tverrfaglig tilnærming. Vi må kunne forutse konsekvensene av at vi mennesker blir flere, bor tettere og reiser mer og konsekvensene av mer intensiv husdyrdrift og økt avskoging. I tillegg bør vi overvåke smittestoffene som sirkulerer hos ville dyr og forutse hvordan endrede samspill mellom mennesker, dyr og miljø kan påvirke utvekslingen av mikroorganismer mellom dyr og mennesker. Sosiologiske faktorer som driver folks adferd, må også med i likningen.

Etter mange år med forbedret folkehelse i mange land har avstanden mellom humanmedisinen og veterinærmedisinen dessverre økt. To fagområder, tidligere tett sammenvevet, strever nå med samspillet. Norges første veterinærdirektør, Ole Olsen Malm, var lege og veterinær, og satt zoonosene høyt på agendaen. Ved å knytte sammen de to fagområdene la han et solid fundament for dagens gode folkehelse og dyrehelse i Norge.

Én helse forener vitenskapene viet til studier av menneskelig sykdom, ikke-human sykdom og $ø$ kologiske problemer. Tverrfaglig forskning, overvåkning og informasjonsdeling bør være grunnlaget for praktiske intervensjoner lokalt, nasjonalt og internasjonalt. Det bør involvere beslutningstakere, leger, veterinærer, økologer samt andre natur- og samfunnsvitere. Dersom verdenssamfunnet skal lykkes med å forhindre fremtidens pandemier, er tverrfaglig og internasjonal forskning og kunnskapsgenerering nødvendig. Det er i norsk interesse å bidra til det.

\section{LITTERATUR}

1. Hu B, Zeng LP, Yang XL et al. Discovery of a rich gene pool of bat SARS-related coronaviruses provides new insights into the origin of SARS coronavirus. PLoS Pathog 2017; 13: e1006698. [PubMed] [CrossRef]

2. Grøntvedt $\mathrm{CA}$, Er C, Gjerset $\mathrm{B}$ et al. Influenza $\mathrm{A}\left(\mathrm{H}_{1} \mathrm{~N} 1\right)$ pdmog virus infection in Norwegian swine herds 2009/10: the risk of human to swine transmission. Prev Vet Med 2013; 110: 429-34. [PubMed] [CrossRef]

3. Cutler SJ, Fooks AR, van der Poel WH. Public health threat of new, reemerging, and neglected zoonoses in the industrialized world. Emerg Infect Dis 2010; 16: 1-7. [PubMed][CrossRef]

4. Wang LF, Anderson DE. Viruses in bats and potential spillover to animals and humans. Curr Opin Virol 2019;34:79-89. [PubMed][CrossRef] 
5. Schountz T, Baker ML, Butler J et al. Immunological control of viral infections in bats and the emergence of viruses highly pathogenic to humans. Front Immunol 2017; 8: 1098. [PubMed] [CrossRef]

6. Chua KB, Chua BH, Wang CW. Anthropogenic deforestation, El Niño and the emergence of Nipah virus in Malaysia. Malays J Pathol 2002; 24: 15-21. [PubMed]

Publisert: 15. mars 2020. Tidsskr Nor Legeforen. DOI: 10.4045/tidsskr.20.0212

(c) Tidsskrift for Den norske legeforening 2023. Lastet ned fra tidsskriftet.no 26. april 2023. 